\title{
Body Image Sebagai Faktor Penentu dalam Meningkatkan Status Gizi Remaja Putri
}

\author{
Ni Nyoman Ayu Dwi Astini ${ }^{1 *}$, Wigutomo Gozali ${ }^{2}$ iD \\ 1,2 Program Studi DIII Kebidanan, Universitas Pendidikan Ganesha, Singaraja, Indonesia \\ *Corresponding author: Astini89@gmail.com
}

\begin{abstract}
Abstrak
Ketidakpuasan terhadap bentuk tubuh seringkali dijumpai pada remaja putri, hal ini membuat remaja putri menerapkan perilaku yang tidak tepat dalam mencapai tubuh ideal dengan melakukan diet yang ketat sehingga berdampak negative pada status gizi. Penelitian ini bertujuan untuk menganalisis hubungan antara body image dengan status gizi remaja putri. Penelitian ini menggunakan metode studi crossectional, dengan jumlah populasi sebanyak 48 orang remaja putri. Pemilihan sampel dilakukan dengan teknik sampel jenuh. Teknik pengumpulan data dilakukan dengan menyebarkan kuiosioner berupa angket kepada sampel penelitian. Data status gizi diperoleh dari pengukuran TB dan BB, selanjutnya dihitung nilai z-score berdasarkan BMI/U dari WHO. Uji hubungan yang digunakan adalah korelasi Rank Spearman. Hasil penelitian menunjukkan bahwa sebanyak 22 subyek $(48,8 \%)$ merasa tidak puas terhadap bentuk tubuhnya dan 26 subyek $(54,2 \%)$ merasa puas dengan bentuk tubuhnya, sedangkan status gizi kurang 2,1\%, status gizi lebih 58,3\% dan normal 39,6\%. Hasil analisa statistic Rank Spearman didapatkan nilai rho $=0,338$ dengan signifikansi $=0,009$. Ini menunjukkan terdapat hubungan positif dan signifikan antara body image dan status gizi. Sehingga dapat ditarik kesimpulan bahwa terdapat hubungan antara body image dan status gizi pada remaja putri.
\end{abstract}

Keywords: Body Image, Status Gizi, Remaja Putri

\section{Abstract}

The dissatisfaction with their body shape is commonly found among female adolescents. The lack of the contentment lead them to gain an ideal body shape but, unfortunately, they implement improper eating behavior. The extreme diet they have affects negatively to their nutritional status. This study was aimed at analyzing the association between the body image with nutritional status of female adolescents. The study was cross-sectional on 48 female adolescents. The samples were taken based on total sampling. The data were gathered by using questionnaire. : Nutritional status data was obstained by measuring weight and height. Then, $z$-score was calculated based on BMI/U by using WHO. A total of 22 subyek $(48,8 \%)$ were not satisfied with their body shape and 26 subyek (54,2\%) were satisfied with their body shape. While nutritional status less $2,1 \%$, nutritional status more 58,3\%, and nutritional status normal 39,6\%. There were significant association between body image with nutritional status $(r=0,338 p=0,009)$. Body image were associated with nutritional status of female adolescents.

Keywords: Body image, nutritional status, female adolescents

\section{Introduction}

Usia remaja dimulai dari usia 10-13 tahun, pada usia ini seorang individu mengalami masa peralihan dari anak-anak menjadi dewasa yang kemudian berakhir pada usia 18-22 tahun (Agustiningsih et al., 2020). Remaja pada usia 15-19 tahun mengalami perubahan fisik dan perubahan psikologis yang cepat. Perubahan fisik akan menimbulkan dampak pada psikologis pada remaja, dimana remaja akan lebih memperhatikan bentuk tubuh khususnya pada remaja putri, sehingga ada kecenderungan untuk membatasi asupan makanan agar berat badan tidak berlebih (Wahyuni \& Aurellia, 2021).

Penilaian remaja putri saat ini cenderung menginginkan penampilan fisik atau body image yang proporsional. Body image merupakan imajinasi subyektif seseorang mengenai

$\begin{array}{ll}\text { History: } & \\ \text { Received } & \text { : 10 Januari } 2021 \\ \text { Revised } & \text { : 09 Februari } 2021 \\ \text { Accepted } & : 06 \text { Maret } 2021 \\ \text { Published } & : 25 \text { April } 2021\end{array}$


bentuk tubuh dan cenderung berkaitan dengan penilaian seseorang, dimana bentuk tubuh yang dimilikinya harus sesuai dengan persepsi orang lain (Denich \& Ifdil, 2015; Husna \& Rusli, 2008). Body image akan menunjukkan seberapa jauh seorang individu merasa puas terhadap bagian-bagian tubuh dan penampilan fisik yang dimilikinya secara keseluruhan (Hasmalawati, 2017). Body image dapat dipengaruhi oleh beberapa faktor seperti faktor psikologis, pengaruh budaya, teman sebaya, etnis, dan media massa. Media masa memiliki peran penting dalam mempengaruhi body image seseorang, dimana media masa mampu mempromosikan bentuk tubuh ideal yang kemudian menjadi terinternalisasi dalam diri seseorang untuk memiliki bentuk tubuh yang ideal (Putra, 2015).

Body image dapat dikelompokkan menjadi body image positif dan body image negatif. Body image prositif memiliki arti bahwa seseorang telah mampu menghargai dan menerima segala kekurangan yang dimiliki oleh tubuhnya (Ramanda et al., 2019). Seseorang yang memiliki body image positif cenderung memiliki memiliki kepuasan terhadap kondisi tubuh yang dimilikinya serta menghargai diri sendiri, menjaga tubuh dengan baik, dan memiliki kepercayaan diri (Andiyati, 2016). Sedangkan body image negatif merupakan bentuk pandangan negatif individu terhadap bentuk tubuh yang dimilikinya (Maryam, 2019). Body image negatif biasanya akan mempengaruhi kondisi psikologis individu dan menyebabkan individu memiliki rasa percaya diri yang kurang dan enggan untuk bertemu orang lain (Sugiar \& Dieny, 2018). Seseorang yang memiliki body image negatif akan melakukan berbagai upaya untuk memiliki bentuk tubuh yang proporsional termasuk melaksanakan diet ketat yang berakibat pada penurunan kualitas gizi serta menyebabkan munculnya berbagai macam penyakit.

Pada umumnya remaja putri menginginkan bentuk tubuh yang tinggi dan langsing dengan melakukan diet dengan tidak memperhatikan kaidah gizi dan kesehatan, akibatnya asupan gizi secara kuantitas dan kualitas tidak sesuai dengan Angka Kecukupan Gizi (AKG ) yang dianjurkan (Denich \& Ifdil, 2015). Pentingnya pemenuhan gizi pada remaja putri berkaitan dengan perannya dimasa yang akan datang, kondisi seseorang pada masa dewasa ditentukan oleh keadaan pada masa remaja. Remaja putri harus memperhatikan asupan gizi serta kesehatan karena remaja putri sebagai calon ibu yang akan melahirkan generasi berikutnya. Masalah gizi yang paling sering muncul adalah kelebihan asupan gizi yang dapat menyebabkan obesitas (Merita \& Djayusmantoko, 2020). Obesitas pada remaja putri membawa beberapa konsekuensi, seperti diskriminasi dari teman-teman, penilaian negative dari diri sendiri, adanya keterbatasan dalam melakukan sosialisasi serta depresi.

Penelitian yang dilakukan oleh (Pratiwi et al., 2018) mengenai hubungan antara pola makan dan pengetahuan gizi dengan body image remaja putri menunjukkan hasil bahwa pola makan dan pengetahuan tentang gizi terhadap body image remaja putri. Hasil yang berbeda ditunjukkan oleh (Ovita et al., 2019) yang menunjukkan hasil sebaliknya, dimana body image berhubungan dengan status gizi remaja putri, dimana apabila remaja body image yang positif maka status gizinya akan baik, begitu pula berlaku sebaliknya. Hal ini didukung oleh penelitian yang dilakukan oleh (Hendarini, 2018) yang juga menyatakan bahwa pola makan dan body image berhubungan dengan status gizi dengan hasil status gizi overweight $(42.8 \%)$ dan body image negative (51.5\%) sedangkan pola makan kurang (53.3\%). Berdasarkan pada latar belakang serta kajian relevan diatas maka akan dilaksanakan penelitian mengenai analisa hubungan antara body image dengan satus gizi pada remaja putri di Prodi D3 Kebidanan FOK Undiksha. Penelitian ini bertujuan untuk mengetahui hubungan antara body image dengan status gizi pada remaja putri di Prodi D3 Kebidanan Fakultas Olahraga dan Kesehatan Undiksha, yang belum pernah dilaksanakan oleh peneliti sebelumnya. 


\section{Materials and Methods}

Penelitian ini merupakan penelitian observasional dengan rancangan cross sectional. Populasi dalam penelitian ini adalah remaja putri di Prodi D3 Kebidanan Fakultas Olahraga dan Kesehatan Undiksha berjumlah 48 orang. Penarikan sampel dilakukan dengan menggunakan menggunakan teknik sampel jenuh, yakni menggunakan seluruh anggota populasi sebagai sampel. Instrumen penelitian yang digunakan dalam penelitian ini menggunakan kuesioner Body Shape Quesstionnare (BSQ) untuk mengukur body image yang terdiri dari 34 pertanyaan dengan rentang skala 1 (tidak pernah) sampai 6 (selalu). Hasil skala body image kemudian di diinterprestasikan dalam 2 katagori, yaitu puas terhadap bentuk tubuh (skor $\leq 38$ dan tidak puas terhadap bentuk tubuh (skor $\geq 38$ ). Untuk data status gizi diperoleh dari pengukuran antropometri terhadap responden. Berat badan diukur dengan timbangan digital dengankapasitas $150 \mathrm{~kg}$ dengan ketelitian $0,1 \mathrm{~kg}$ dan pengukuran tinggi badan menggunakan microtoise dengan kapasitas $200 \mathrm{~cm}$ dengan ketelitian $0,1 \mathrm{~cm}$. Berikutnya status gizi ditentukan berdasarkan perhitungan IMT kemudian dikonversikan ke dalam nilai z-score BMI/U. Analisa data yang digunakan dalam penelitian ini adalah menggunakan uji Rank Spearman.

\section{Results and Discussion \\ Hasil}

Hasil penelitian mengenai karakteristik body image remaja putri Prodi D3 Kebidanan Fakultas Olahraga dan Kesehatan Undiksha disajikan pada Tabel 1.

Tabel 1. Distribusi Karakteristik Responden Menurut Body Image Remaja Putri

\begin{tabular}{lcc}
\hline \multicolumn{1}{c}{ Variabel Body Image } & Jumlah & Presentase (\%) \\
\hline Positif/Puas & 26 & 54,2 \\
Negatif/Tidak Puas & 22 & 45,8 \\
\hline Total & $\mathbf{4 8}$ & $\mathbf{1 0 0}$ \\
\hline
\end{tabular}

Berdasarkan Tabel 1, mayoritas remaja putri di Prodi DIII Kebidanan Fakultas Olahraga dan Kesehatan Undiksha mempunyai gambaran body image negatif sebanyak 26 orang $(54,2 \%)$ sedangkan yang memiliki body image positif sebanyak 22 orang $(45,8 \%)$. Selanjutnya hasil penelitian mengenai status gizi 48 orang remaja putri di Prodi DIII Kebidanan Fakultas Olahraga dan Kesehatan Undiksha dapat dilihat pada Tabel 2.

Tabel 2. Distribusi Karakteristik Responden Menurut Status Gizi Remaja Putri

\begin{tabular}{lccc}
\hline & Variabel Status Gizi & Jumlah & Presentase (\%) \\
\hline Kurang & 1 & 2,1 \\
Lebih & 28 & 58,3 \\
Normal & 19 & 39,6 \\
\hline Total & $\mathbf{4 8}$ & $\mathbf{1 0 0}$ \\
\hline
\end{tabular}

Berdasarkan Tabel 2 menunjukkan bahwa sebagian besar responden memiliki status gizi lebih sebesar 28 orang (58,3\%), dengan status gizi normal 19 orang (39,6\%) sedangkan yang memiliki status gizi kurang sebanyak 1 orang $(2,1 \%)$. Hubungan mengenai body image dengan status gizi pada remaja putri di Prodi DIII Kebidanan Fakultas Olahraga dan Kesehatan Undiksha dapat dilihat pada Tabel 3. 
Tabel 3. Tabulasi Silang antara Body Image dengan Status Gizi Remaja Putri

\begin{tabular}{ccccccc}
\hline & \multicolumn{4}{c}{ Body Image } & \multicolumn{3}{c}{ Total } \\
\cline { 2 - 5 } Status Gizi & \multicolumn{2}{c}{ Positif/puas } & \multicolumn{2}{c}{ Negatif/tidak puas } & & \\
\cline { 2 - 5 } & $\mathbf{n}$ & $\mathbf{\%}$ & $\mathbf{n}$ & $\mathbf{\%}$ & $\mathbf{n}$ & $\boldsymbol{\%}$ \\
\hline Gizi Kurang & 0 & 0 & 1 & 2,1 & 1 & 2,1 \\
Gizi Lebih & 12 & 25 & 16 & 33,3 & 28 & 58,3 \\
Gizi Normal & 14 & 29,2 & 5 & 10,4 & 19 & 39,6 \\
\hline Total & $\mathbf{2 6}$ & $\mathbf{5 4 , 2}$ & $\mathbf{2 2}$ & $\mathbf{4 5 , 8}$ & $\mathbf{4 8}$ & $\mathbf{1 0 0}$ \\
\hline
\end{tabular}

Berdasarkan Tabel 3 menunjukkan hasil bahwa dari 26 orang (54,2 \%) yang mengalami body image positif tidak hanya terjadi pada subyek dengan kelebihan berat badan saja, namun juga pada subyek dengan status gizi normal yaitu sebanyak 14 orang $(29,2 \%)$. Sedangkan pada yang mengalami body image negatif sejumlah 22 orang (45,8\%) ada 1 orang $(2,1 \%)$ yang mengalami gizi kurang. Berdasarkan hasil analisa antara body image dengan status gizi menunjukkan adanya korelasi yang bermakna ( $r=0,338 \rho=0,009)$. Hal ini berarti semakin tinggi ketidakpuasan atau memiliki gambaran negatif terhadap body image, maka status gizinya semakin tidak normal (obesitas)

\section{Pembahasan}

Temuan pertama, mengenai karakteristik body image remaja putri Prodi D3 Kebidanan Fakultas Olahraga dan Kesehatan Undiksha menunjukkan bahwa bahwa sebanyak 26 subyek $(54,2 \%)$ puas terhadap bentuk tubuhnya dan sebanyak 22 subyek $(45,8 \%)$ merasa tidak puas terhadap bentuk tubuhnya. Pengetahuan remaja akan menjadikan remaja mempunyai persepsi terhadap suatu hal, sehingga akan mempengaruhi sikap dan perilaku seorang remaja. Banyak remaja yang merasa tidak puas dengan penampilan dirinya sendiri apalagi yang menyangkut tentang body image. Remaja menginginkan bentuk tubuh tinggi dan langsing namun pada kenyataannya banyak remaja putri yang merasa tidak puas dengan ukuran dan bentuk tubuhnya. Hal ini sejalan dengan hasil penelitian yang dilakukan oleh (Tarigan et al., 2005) yang menunjukkan bahwa $67 \%$ remaja obesitas dan $33 \%$ remaja yang tidak obesitas menyatakan ketidakpuasannya terhadap body image. Berdasarkan hasil penelitian tersebut dapat diketahui bahwa remaja putri cenderung lebih memperhatikan body image, hal ini dikarenakan pada tahap remaja menengah (middle adolescence) remaja putri lebih fokus memperhatikan penampilan sehingga mereka berusaha untuk meningkatkan perhatian terhadap bentuk tubuhnya dengan melakukan sesuatu agar penampilan fisiknya terlihat lebih baik (Defika \& Desiningrum, 2016; Nurjannah \& Muniroh, 2019). Hal tersebut juga disebabkan karena remaja putri lebih mudah dipengaruhi oleh media masa dan trend saat ini (Denich \& Ifdil, 2015).

Temuan kedua, Berdasarkan hasil penelitian menunjukkan bahwa sebagian besar responden status gizinya lebih, namun masih ada responden yang berstatus gizi kurang. Hasil penelitian ini menunjukkan bahwa prevalensi gizi lebih di Prodi D3 Kebidanan Fakultas Olahraga dan Kesehatan Undiksha lebih tinggi jika dibandingkan dengan prevalensi status gizi kurang. Penemuan tersebut sesuai dengan data Riskesdas 2010 dimana status masalah gizi pada kelompok remaja usia 17-19 tahun didominasi dengan masalah gizi lebih dan lebih banyak terjadi di wilayah perkotaan. Banyaknya masalah gizi yang terjadi pada remaja dapat disebabkan oleh berbagai faktor antara lain adalah konsumsi makanan dan tingkat kesehatan (Margiyanti, 2021).

Masalah gizi pada remaja putri dapat diakibatkan oleh diet yang ketat (yang menyebabkan remaja kurang mendapat makanan yang seimbang dan bergizi serta kebiasaan makan yang buruk (Pantaleon, 2019). Sebagian remaja putri memilih melewatkan dua kali 
waktu makan dan lebih memilih makanan jajanan yang sebagian besar mengandung sedikit kalori dan sedikit zat gizi (Hendarini, 2018). Tidak sedikit survey yang mencatat ketidakcukupan asupan gizi para remaja akibat kebiasaan mengkonsumsi makanan jajanan yang berlebih. Hal-hal lain yang mempengaruhi status gizi remaja putri diantaranya yaitu faktor keturunan, gaya hidup dan faktor lingkungan (Herdiani et al., 2021).

Body image pada umumnya dialami oleh mereka yang menganggap bahwa penampilan adalah faktor yang paling penting dalam kehidupan (Alidia \& Bimbingan, 2018). Hal ini terutama terjadi pada usia remaja. Mereka beranggapan bahwa tubuh yang kurus dan langsing adalah yang idel bagi wanita, sedangkan tubuh yang kekar dan berotot adalah yang idel bagi pria (Ramanda et al., 2019). Dalam penelitian ini, komponen body image yang dinilai adalah persepsi, yaitu berhubungan dengan ketepatan individu dalam mempersepsikan atau memperkirakan ukuran tubuhnya.

Temuan ketiga, hasil analisa menunjukan body image berhubungan dengan status gizi dengan $\mathrm{r}=0,338, \mathrm{p}=0,009$. Hal tersebut mendukung penelitian yang dilakukan oleh Laus dkk yang menyatakan bahwa terdapat hubungan antara body image dengan status gizi ( $\mathrm{r}$ $=0,37, \mathrm{p}=<001)$. Ketidakpuasan terhadap bentuk tubuh pada remaja dengan menganggap tubuhnya terlalu gemuk membuat remaja melakukan upaya penurunan berat badan dengan cara yang salah, sehingga hal tersebut akan mempengaruhi status gizi remaja tersebut. Pola konsumsi dan pemilihan makanan yang dilakukan oleh remaja putri juga dipengaruhi oleh banyak faktor, antara lain faktor social ekonomi, faktor pengetahuan tentang gizi, dan penyakit-penyakit infeksi yang juga dapat mempengaruhi pola konsumsi seorang remaja putri. Remaja putri dengan body image negatif yang memiliki pengetahuan gizi yang bagus dinilai lebih baik dalam memilih makanan yang mereka konsumsi sehingga penilaian negative tentang body imagenya tidak akan mempengaruhi status gizinya. Mereka mungkin berpikir bahwa tubuh mereka tidaklah ideal, tetapi kesadaran mereka akan pentingnya status gizi akan membuat mereka berpikir ulang ketika akan melakukan diet ketat. Kesadaran akan status gizi itulah yang akan menjadi lebih berpengaruh dalam pemilihan konsomsi seorang remaja.

\section{Conclusion}

Hasil penelitian ini menunjukkan bahwa terdapat hubungan yang bermakna antara body image dengan status gizi pada remaja putri. Semakin tinggi ketidakpuasan terhadap body image maka status gizinya semakin tidak normal (overweight). Terdapat pula subyek yang memiliki status gizi normal namun merasa tidak puas dengan bentuk tubuhnya. Ada hubungan antara body image dengan status gizi. Bagi remaja putri agar lebih memperhatikan status gizinya dengan cara memantau secara berkala berat badan dan tinggi badannya sehingga dapat mengetahui status gizinya serta diharapkan agar mampu mengubah persepsi mengenai body imagenya dengan cara meningkatkan kepercayaan diri dan lebih memfokuskan pada kelebihan dirinya, serta tidak membanding-bandingkan diri sendiri dengan orang lain. Untuk penelitian lebih lanjut yang berkaitan dengan perilaku makan, disarankan untuk dilakukan secara langsung yaitu dengan mengobservasi perilaku makan responden serta menganalisis asupan makan secara kuantitatif.

\section{References}

Agustiningsih, N., Rohmi, F., \& Rahayu, Y. E. (2020). Hubungan Body Image Dengan Harga Diri Pada Remaja Putri Usia 16-18 Tahun. Jurnal Ilmu Kesehatan, 8(2), 109-115. https://doi.org/https://doi.org/10.32831/jik.v8i2.244.

Alidia, F., \& Bimbingan, P. (2018). Body Image Siswa Ditinjau Dari Gender. Jurnal Tarbawi: Jurnal Ilmu Pendidikan, 14(02), 79-92. https://doi.org/https://doi.org/10.32939/tarbawi.v14i2.291. 
Andiyati, A. D. W. (2016). Hubungan Antara Body Image Dengan Kepercayaan Diri Siswa Kelas X DI SMA Negeri 2 Bantul. Journal Bimbingan Dan Konseling Edisi, 5(4), 8088. http://journal.student.uny.ac.id/ojs/ojs/index.php/fipbk/article/view/1157/1031.

Defika, M., \& Desiningrum, D. R. (2016). Hubungan Antara Minat Mengikuti Yoga Class Dengan Body Image Pada Remaja Putri Di Fitness Centre Semarang. Jurnal Empati, 5(April), 308-311. https://ejournal3.undip.ac.id/index.php/empati/article/view/15234.

Denich, A. U., \& Ifdil, I. (2015). Konsep Body Image Remaja Putri. Jurnal Konseling Dan Pendidikan, 3(2), 55. https://doi.org/10.29210/116500.

Hasmalawati, N. (2017). Pengaruh Citra Tubuh Dan Perilaku Makan Terhadap Penerimaan Diri Pada Wanita. Jurnal Psikoislamedia, 2(2), 107-115. https://doi.org/10.22373/psikoislamedia. v2i2.1892.

Hendarini, A. (2018). Pengaruh body image dan kebiasaan makan dengan status gizi di SMAN 1 Kampar tahun 2017. Jurnal Gizi, 2(2), 138-145. https://journal.universitaspahlawan.ac.id /index.php/jurnalgizi/article/view/200.

Herdiani, T. N., Manujung, V. H., \& Mutiara, V. S. (2021). Study Literature Review FaktorFaktor Yang Berhubungan Dengan Status Gizi Remaja Putri. CHMK MIDWIFERY Scientific Journal, 4(1), 243-257. http://cyberchmk.net/ojs/index.php/bidan/article/view/967/344.

Husna, R., \& Rusli, D. (2008). Pengaruh Body Image Terhadap Self-Esteem Pada Remaja Fans K-Pop. Bariatric Nursing and Surgical Patient Care, 3(4), 241-248. https://doi.org/10.1089/bar.2008.9953.

Margiyanti, N. J. (2021). Analisis Tingkat Pengetahuan , Body Image dan Pola Makan terhadap Status Gizi Remaja Putri. Jurnal Akademka Baiturrahim Jambi, 10(1), 231237. https://doi.org/10.36565/jab.v10i1.341.

Maryam, S. (2019). Hubungan body image dengan penerimaan diri mahasiswa putri Relationship between body image and self-acceptance of female students. Jurnal Aplikasi IPTEK Indonesia, 3(3), 129-136. https://doi.org/https://doi.org/10.24036/4.13148.

Merita, N. H., \& Djayusmantoko. (2020). Persepsi Citra Tubuh, Kecenderungan Gangguan Makan Dan Status Gizi Pada Remaja Putri Di Kota Jambi. Journal of Nutrition College, 9(2), 2-7. http://ejournal3.undip.ac.id/index.php/jnc/.

Nurjannah, I., \& Muniroh, L. (2019). Body Image , Tingkat Kecukupan Zat Gizi , Dan Fad Diets Pada Model Remaja Putri Di Surabaya. Jurnal Semantik, 14(1), 95-105. https://doi.org/https://doi.org/10.204736/mgi.v14i1.95-105.

Ovita, A. N., Hatmanti, N. M., \& Amin, N. (2019). Hubungan Body Image Dan Aktivitas Fisik Dengan Status Gizi Remaja Putri Kelas Viii Smpn 20 Surabaya. Sport and Nutrition Journal, 1(1), 27-32. https://doi.org/10.15294/SPNJ.V1I1.31275.

Pantaleon, M. G. (2019). Hubungan Pengetahuan Gizi Dan Kebiasaan Makan Dengan Status Gizi Remaja Putri Di SMA Negeri II Kota Kupang. CHMK HEALTH Journal, 3(3). http://cyber-chmk.net/ojs/index.php/kesehatan/article/view/513/203.

Pratiwi, A., Susilowati, Y., \& Febriana, D. (2018). Hubungan Antara Pola Makan Dan Pengetahuan Gizi Dengan Body Image Remaja Putri Di SMAN 24 Kabupaten Tangerang Tahun 2018. Jurnal Kesehatan, 7(2). https://doi.org/10.37048/kesehatan.v7i2.169.

Putra, A. (2015). Body Image dan Hubungannya dengan Aktivitas Berolahraga. Jurnal Penjakora, 2(2), 88-97. https://doi.org/http://dx.doi.org/10.23887/penjakora.v2i2.11486.

Ramanda, R., Akbar, Z., \& Wirasti, R. A. M. K. (2019). Studi Kepustakaan Mengenai Landasan Teori Body Image Bagi Perkembangan Remaja. Jurnal Bimbingan 
Konseling, 5(2), 120-135. https://doi.org/http://dx.doi.org/10.22373/je.v5i2.5019.

Sugiar, I. E., \& Dieny, F. F. (2018). Hubungan Body Image Dengan Asupan Energi Dan Protein Serta Perilaku Konsumsi Suplemen Pada Mahasiwa Di Semarang. Journal of Nutrition College, 7(1), 3-10. https://doi.org/https://doi.org/10.14710/jnc.v7i1.20779.

Tarigan, N., Hadi, H., \& Julia, M. (2005). Hubungan Citra Tubuh Dengan Status Obesitas, Aktivitas Fisik Dan Asupan Energi Remaja Sltp Di Kota Yogyakarta Dan Kabupaten Bantul. Jurnal Gizi Klinik Indonesia, 1(3), 130-136. https://doi.org/https://doi.org/10.22146/ijen.17428.

Wahyuni, N. S., \& Aurellia, A. (2021). Hubungan Body Image dengan Harga Diri pada Remaja Putri Penggemar Kpop di Komunitas A . R . M . Y Medan. Journal of Education, Humaniora and Social Sciences (JEHSS), 3(3), 1365-1371. https://doi.org/10.34007/jehss.v3i3.566. 